\title{
Elżbieta Dubas, Joanna Stelmaszczyk (red.) Biografie i uczenie się, seria wydawnicza „Biografia i badanie biografii”, t. 4, Wy- dawnictwo Uniwersytetu Łódzkiego, Łódź 2015, ss. 219.
}

\author{
Jeśli nie chcemy żyć z dnia na dzień, \\ ale pragniemy w pełni świadomie przeżywać własną egzystencję, \\ wówczas naszą największą potrzebą i najtrudniejszym zadaniem \\ jest znalezienie jej sensu (Bettelheim, 1996, s. 21)
}

\section{Wstęp}

Czytanie książki Biografie i uczenie się pod red. Elżbiety Dubas i Joanny Stemaszczyk zmusiło mnie do poszukiwań i podjęcia pewnej rewizji pojęciowej, przede wszystkim dwóch kategorii, jakimi są biografia i całożyciowe uczenie się. Treści zawarte w książce są dla mnie bardziej pewnymi „tropami” niż jakimś konkretnym konstruktem teoretycznym.

Współcześnie twierdzenie, iż perspektywa biograficzna przeżywa dziś swój renesans jest według mnie już truizmem. Ponieważ od kilku dekad posługują się nią nie tylko pedagodzy czy socjolodzy, powołujący się na ugruntowaną w obrębie tych dyscyplin tradycję badawczą, gdzie za jednego z prekursorów metody biograficznej uznaje się Floriana Znanieckiego. Metoda badawcza dokumentów osobistych lub dokumentów ludzkich zjawiła się, cytując za Janem Szczepańskim (Szczepański, 1971 s. 573), „w bardzo charakterystycznym okresie rozwoju socjologii, mianowicie wtedy, kiedy socjologowie zrezygnowali z tworzenia wielkich syntez wyjaśniających istotę społeczeństwa ludzkiego i ustalających ogólne prawa rozwoju, przechodząc do empirycznych badań nad wybranymi dziedzinami faktów społecznych". Jednym z pierwszych dzieł, w którym ta tendencja znalazła pełen wykaz, była książka Chłop polski w Europie i Ameryce (patrz: Thomas, Znaniecki, Chłop polski w Europie i Ameryce, t. 1-5, Ludowa Spółdzielnia Wydawnicza, Warszawa, 1976). 
„Dzieło Thomasa i Znanieckiego stawiało więc zagadnienia w nowy, empiryczny sposób, przyjmowało nowe założenia ontologiczne co do natury badanych zjawisk społecznych: aby rozwiązać te zagadnienia zgodnie z przyjętymi założeniami, posłużono się nowymi materiałami: dokumentami osobistymi. [...] W ten sposób Thomas i Znaniecki obudzili duże nadzieje związane z wykorzystaniem autobiografii i innych dokumentów osobistych". (Szczepański, 1971 s. 575).

Na gruncie pedagogicznym wpisującym się doskonale w ów nurt badawczy jest (choć często niedoceniony) Janusz Korczak, gdzie chociażby same Pisma wybrane (Janusz Korczak Pisma wybrane, Nasza Księgarnia, Warszawa 1978, t. I-IV) są doskonałym przykładem m.in. badań biograficznych.

Koniecznym pytaniem w kontekście analizowanej tytułowej książki jest: Czy współcześni pedagodzy/nauczyciele/rodzice potrafią wykorzystać biografie w wychowaniu i kształceniu młodszych pokoleń, jak również odnajdywaniu w biografiach kierunkowskazów, mądrości, oparcia w zrelatywizowanym świecie wartości? Czy ich autobiografie w kulturze prefiguratywnej, które Margaret Mead opisuje w Kulturze i tożsamości, gdzie „[...] większość rodziców nie ma jednak dość pewności siebie, by umacniać stare dogmaty. Rodzice nie wiedzą, jak powinni uczyć dzieci, które tak zasadniczo różnią się od nich w młodości, a i większość dzieci nie potrafi uczyć się od rodziców i starszych, do których nigdy podobna nie będzie" (Mead, 2000, s. 118). To właśnie nierozumienie biograficznej jednostkowej przygodności człowieka powoduje zagubienie się człowieka w budowaniu tożsamości, jak i brak umiejętności wykorzystania biografii w procesie całożyciowego uczenia się, o której pisał już Jan Amos Komeński w Pampaedii, cytując, że każdy wiek jest odpowiedni do uczenia się, a życie ludzkie nie ma innego celu, jak nauka (Jan Amos Komeński, 1973, s. 67). Choć we wstępie recenzowanej pracy czytamy „[...] Całość opracowania to kolejny krok autorów - badaczy zainteresowanych, a nawet zafascynowanych podejściem biograficznym, dokonany w kierunku poszerzenia i pogłębienia wiedzy o biografii: jej wydobywaniu i tworzeniu, o jej zawartości i znaczeniu, o sposobach badania i interpretacji" (Dubas, 2015, s. 10). Żałuję tylko, że myśl Komeńskiego nie jest obecna w analizowanej książce, co nadałoby jej większej wartości, mimo deklarowanego zafascynowania podejściem biograficznym m.in. w perspektywie całożyciowego uczenia się.

Recenzowany tom z cyklu Biografia i badanie biografii pod red. Elżbiety Dubas i Joanny Stelmaszczyk jest czwartym z serii. Teksty, jak czytamy we wstępie, powstały w latach 2012-2014 w ramach projektu realizowanego od 2008 r. w Zakładzie Andragogiki i Gerontologii Społecznej Uniwersy- 
tetu Łódzkiego z udziałem badaczy z całego kraju. Generalnie można ująć, że treści tego tomu koncertują się wokół tematu, jakim jest uczenie się powiązane z biografią. 15 autorskich tekstów spaja ze sobą biografia i uczenie się w głównych, przenikających się kontekstach: całożyciowości uczenia się, uczenia się z biografii Innych oraz biografii edukacyjnych. Swoją recenzję książki staram się wpisać w trójpodział zaproponowany we wstępie przez Elżbietę Dubas. Choć nie mam podziału na części, zatytułowałam je: I: Dyskurs biograficzny w pedagogice i andragogice, II: Biografia Innych znaczących i zwyczajnych oraz III: Biografie a edukacja.

\section{Dyskurs biograficzny w pedagogice $i$ andragogice}

Elżbieta Dubas trafnie zaznaczyła, że „biografia, tak jak człowiek, jest tajemnicza, pełna znaków zapytania, nie pozwala się w pełni rozpoznać, jest niedomknięta, a przez to tym bardziej intryguje i wciąż stanowi interesujące pole badawcze" (Dubas, 2015, s. 10). To właśnie owa przygodność historii ludzkiej staje się wartością samą w sobie a „Rozum i Teoria, które służyły (i nadal tak się dzieje - przyp. autorki) jako środek, który miał oswobodzić ludzki umysł od zagrażających mu przygodności" (Habermas, 1996, s. 15) tracą na mocy poprzez swoje bezkrytyczne zapatrzenie.

Książkę otwiera tekst E. Dubas Biograficzność w kontekście całożyciowego uczenia się, w którym objaśnia w szczególności teorię biograficzności Petera Alheita, zwracając uwagę na jej ujęcie systemowe. Traktując biograficzność Petera Alheita jako paradygmat w edukacji dorosłych, która to właśnie jest rozumiana przez autorkę tekstu jako „ukryty” paradygmat biograficzności. To właśnie koncepcja biograficzności łączy się z całożyciowym uczeniem się. Wskazując na jej potencjał badawczy, umiejscawia w jej kontekście całożyciowe uczenie się. To właśnie ten tekst wywołał moją ambiwalentną emocję, ze względu na to, że używając, budując - jeżeli można to tak ująć podwaliny pod teoretyczną koncepcję biograficzności jako całożyciowego procesu uczenia się, nie czerpie się chociażby z bogactwa myśli Jana Amosa Komeńskiego, który dobitnie w Pampaedii wykłada nam koncepcję całożyciowego uczenia się.

W drugim tekście Elżbieta Dubas prezentuje aktualnie realizowane w polskiej andragogice badania biograficzne, określając jego zakresy, m.in.: biografię edukacyjną, doświadczenia edukacyjne, potencjał edukacyjny, biograficzne uczenie się, uczenie się z własnej biografii. Autorka, co jest bardzo słuszne, akcentuje, że badania andragogiczne z zastosowaniem podej- 
ścia biograficznego, jak i edukacją, pozwolą zrozumieć procesy uczenia się dorosłych.

Amelia Krawczyk-Bochomulska ukazuje możliwości wykorzystania badań biograficzno-narracyjnych do odkrywania historii życia. Uwypukla i analizuje kontekst narracji w biograficznych badaniach stosowanych w pedagogice. Przedstawia swoją znajomość warsztatu badawczego, który dla wielu badaczy będzie przydatny.

Kolejna autorka - Justyna Sztobryn-Bochomulska udanie połączyła w swoim artykule filozofię z historią oraz pedagogiką. Wykorzystując pojęcia inkontrologii i ergantropii Andrzeja Nowickiego do analizy literatury wspomnieniowej, wskazała jej walory edukacyjne.

\section{Biografia Innych znaczących i zwyczajnych}

Czytanie biografii z zasady daje nam możliwości wejścia bardziej w głąb historii bohatera, jednak to od nas zależy, czy jego historię odłożymy na półkę, czy zacznie ona żyć w nas jako jeden z utęsknionych autorytetów, o których dobitnie pisał w przynajmniej swoich dwóch książkach Lech Witkowski (patrz: Wyzwania autorytetu, 2009; Historie autorytetu. Wobec kultury i edukacji, 2011). Recenzowana książka jest również dowodem na niesłabnące zainteresowanie badaczy biografiami Innych osób - wybitnych i zwyczajnych. Rafał Marcin Leszczyński analizował biografię osoby wybitnej, Czecha Pawła Hulki-Laskowskiego, jako doskonałego przykładu ludzkiej zdolności do przekraczania uwarunkowań społecznych i kulturowych oraz procesów samorozwoju czy całożyciowego uczenia się.

Anna Walczak zaprasza czytelnika na spotkanie biograficzne ze sławną piosenkarką francuską Edith Piaf. Ukazuje, uwzględniając teoretyczną podbudowę narracji i kategorii dramatu, że spotkanie z biografią Innego, przeradza się w spotkanie z samym sobą, co uważam za ważną część recenzowanej książki.

Monika Sulik, na podstawie materiałów autobiograficznych Aleksandra Wata i Oli Watowej, podjęła próbę odszukania i ukazania najistotniejszych fragmentów biografii Aleksandra Wata i jego żony. Jak sama autorka zaznacza, tekst jest bardziej wprowadzeniem czy zaproszeniem do poszukiwań wartości w biografii bohaterów.

Katarzyna Popek swój tekst traktuje jako opowieść (jak z resztą sama go tak nazwała), w której przedstawia losy Stanisława i Haliny jako przykładnego małżeństwa. Podejmuje próbę poznania małżeństwa $z$ długoletnim stażem, by dostrzec wartości płynące $\mathrm{z}$ takiego związku w powiązaniu 
z cechami badanych małżonków i wspólnotą ich losu. Ukazanie wręcz terapeutycznej wartości, jaką jest możliwość podzielenia się z kimś swoimi przeżyciami, pozwala na porządkowanie bilansu życia, które dokonuje się dzięki - parafrazując Milana Kunderę - mądrości powieści, bo wystarczyło przysiąść i wysłuchać.

Olga Czerniawska analizuje dwie biografie: Wspomnienia ojca Józefa Marii Bocheńskiego i Życie Ewangeliq księdza Jana Ziei. Autorka odnosi się do własnego doświadczenia, gdzie wskazuje na różnorodne motywy zapoznania się z biografiami Innych. Również wątek uczenia się z biografii Innych bywa mniej lub bardziej świadomie uwypuklany w prezentowanych opisach - stanowi o ich edukacyjnym wymiarze.

\section{Biografie a edukacja}

Kolejnych sześć tekstów ukazuje szeroki kontekst znaczenia biografii edukacyjnej, która nadal wymaga pogłębionych i wielokierunkowych studiów empirycznych. Agnieszka Majewska-Kafarowska rozpoczyna od rozważań teoretycznych dotyczących biograficzności, m.in. biografii tematycznych, kompetencji autobiograficznych. Odsłania różne aspekty edukacji, które zawarte są w biografiach badanych kobiet. Powraca po czasie do tych samych, wcześniej zgromadzonych narracji, by - jak pisze - zobaczyć to samo z innej perspektywy.

W artykule Joanny Stelmaszczyk zaprezentowana jest analiza porównawcza dróg dwóch absolwentów studiów pedagogicznych Uniwersytetu Łódzkiego. Analiza autorki dotyczy dwóch formom edukacji - formalnej i nieformalnej jako element budowania własnej ścieżki edukacyjnej, poprzez co akcentuje dynamizm rozwojowy i potrzeby edukacyjne.

Agnieszka Domagała-Kręcioch i Bożena Majerek w swoim artykule przedstawiają szkołę z perspektywy szkolnych efektów kształcenia. Retrospektywna analiza prezentowanych esejów biograficznych dotyczyła kompetencji osobistych, społecznych badanych uczniów. Tekst ten jest pewną formą odpowiedzi na problemy związane $\mathrm{z}$ aktualnymi efektami kształcenia w systemie szkolnej edukacji.

Agnieszka Koterwas ukazuje, że szkoła, jako nieunikniony, znaczący fragment życia człowieka, warunkuje jego funkcjonowanie w dorosłym życiu. To właśnie świadomość tych procesów daje możliwości edukatorom, aby uwzględniać badania nad procesami dydaktycznymi jako elementu biografii edukacyjnej, sugerując tym samym nowy zakres badań biografii edukacyjnej jako biografii dydaktycznej. 
Anna Walulik zastosowała wypracowaną przez siebie koncepcję strategii refleksji nad życiem oraz koncepcję Kolba w pracy dydaktycznej ze studentami i poddała analizie w badaniach biograficznych.

Ostatni tekst Agaty Szwech jest wynikiem przygotowanych przez studentki pedagogiki refleksji po przeczytaniu dzienników Haliny Semenowicz. Autorka analizuje edukacyjne oddziaływania biografii na studentach uczestniczących w kierowanym przez siebie projekcie. Wartością dodaną artykułu jest zapewne to, że respondentki poddają się refleksji, aby zacząć pisać swoje dzienniki, wspomnienia.

\section{Zamiast zakończenia}

Recenzowana książka wpisuje się doskonale w nurt myślowy o tożsamości biograficznej, która jest jedną z naczelnych kategorii w analizie ramowej Ervinga Goffmana (2010), stosowana tam wymiennie $z$ kategorią tożsamości osobistej, odsyła do wyobrażenia konkretnej, niepowtarzalnej jednostki, której proces całożyciowego uczenia się, będący wiodącą myślą tego tomu, powinna być dla andragogów/pedagogów nie tylko nośną ideą, którą dla dobra człowieka powinno się wdrażać w funkcjonowanie systemu edukacji (dorosłych), ale nade wszystko ważnym zapytaniem badawczym, hipotezą badawczą oczekującą na empiryczną weryfikację. Pamiętając, że odróżnia się od wszystkich innych jednostek i w której dostrzegamy w pewnej mierze unikalne atrybuty, a pomocna może tu okazać się metoda biograficzna, która za pomocą subtelnego instrumentarium wywiadu narracyjnego, jest w stanie zidentyfikować pułapki biograficzne, polegające na pozornej autonomii i zarazem faktycznym wyobcowaniu jednostki, przesłanianym za pomocą zużytych schematów dyskursu podmiotowej sprawczości albo poddawanym próbom pracy nad własną biografią.

Izabela Symonowicz-Jabłońska

\section{Bibliografia}

Bettelheim B. (1996), Cudowne i pożyteczne. O znaczeniach i wartościach baśni, przeł. D. Danek, Agencja Wydawnicza Jacek Santorski\& Co, Warszawa.

Goffman E. (2010), Analiza ramowa. Esej z organizacji doświadczenia, przeł. S. Burdziej, Nomos, Kraków.

Habermas J., Rorty R., Kołakowski L., (1996), Stan filozofii wspótczesnej, przekł. J. Niżnik, Wydawnictwo IFiS PAN, Warszawa. 


\section{4 | Biografie i uczenie się}

Korczak J. (1978), Pisma wybrane, t. I-IV, Nasza Księgarnia, Warszawa.

Komeński J. A. (1973), Pampaedia, przeł. K. Remerowa, Zakład Narodowy Imienia Ossolińskich, Wydawnictwo Polskiej Akademii Nauk, Wrocław-Warszawa-Kraków- Gdańsk.

Mead M., (2000), Kultura i tożsamość. Studium dystansu międzykulturowego, przeł. J. Hołówka, Wydawnictwo Naukowe PWN, Warszawa.

Szczepański J. (1971), Odmiany czasu teraźniejszego, Książka i Wiedza, Warszawa. 